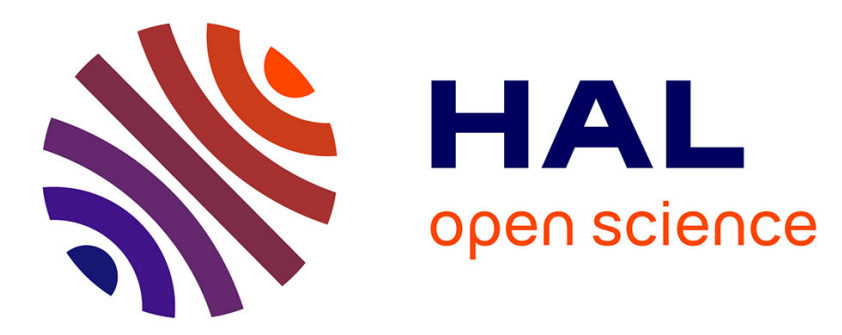

\title{
The mangrove pump: The tidal flushing of animal burrows in a tropical mangrove forest determined from radionuclide budgets
}

Thomas Stieglitz, Jordan F. Clark, Gary J. Hancock

\section{- To cite this version:}

Thomas Stieglitz, Jordan F. Clark, Gary J. Hancock. The mangrove pump: The tidal flushing of animal burrows in a tropical mangrove forest determined from radionuclide budgets. Geochimica et Cosmochimica Acta, 2013, 102, pp.12-22. 10.1016/j.gca.2012.10.033 . hal-00788217

\section{HAL Id: hal-00788217 \\ https://hal.univ-brest.fr/hal-00788217}

Submitted on 26 Apr 2013

HAL is a multi-disciplinary open access archive for the deposit and dissemination of scientific research documents, whether they are published or not. The documents may come from teaching and research institutions in France or abroad, or from public or private research centers.
L'archive ouverte pluridisciplinaire HAL, est destinée au dépôt et à la diffusion de documents scientifiques de niveau recherche, publiés ou non, émanant des établissements d'enseignement et de recherche français ou étrangers, des laboratoires publics ou privés. 


\title{
The mangrove pump: The tidal flushing of animal burrows in a tropical mangrove forest determined from radionuclide budgets
}

\author{
Thomas C. Stieglitz ${ }^{\mathrm{a}, \mathrm{b}, \mathrm{c}, \mathrm{d}, *}$, Jordan F. Clark ${ }^{\mathrm{e}}$, Gary J. Hancock ${ }^{\mathrm{f}}$ \\ ${ }^{a}$ School of Engineering \& Physical Sciences, James Cook University, Townsville, Qld 4811, Australia \\ ${ }^{\mathrm{b}}$ Australian Institute of Marine Science, PMB No. 3, Townsville, Qld 4810, Australia \\ cAIMS@JCU, Townsville, Australia \\ ${ }^{\mathrm{d}}$ Centre for Tropical Water and Aquatic Ecosystem Research, James Cook University, Townsville, Qld 4811, Australia \\ ${ }^{\mathrm{e}}$ Earth Science \& Environmental Studies, University of California, Santa Barbara, CA 93106, USA \\ ${ }^{\mathrm{f}}$ CSIRO Land \& Water, Canberra, Australia
}

Received 26 January 2012; accepted in revised form 10 October 2012; available online 30 October 2012

\begin{abstract}
Intertidal mangrove forests contribute significantly to biogeochemical solute budgets of tropical and subtropical coastlines. A significant part of the biogeochemical cycling in mangrove ecosystems occurs within the subsurface of the forest floor. This subsurface source and the 'offshore' sink are linked by the tidally-driven movement of water through the mangrove forest floor. The tidal circulation through animal macro-burrows in the Coral Creek mangrove forest (area $3 \mathrm{~km}^{2}$ ) on Hinchinbrook Island (Australia) is documented by constructing mass balances of isotopes of radium and radon measured in the creek in 1997 and 2005 respectively. Isotope activities in burrows were found to be significantly greater than in the adjacent mangrove creek (e.g. for ${ }^{222} \mathrm{Rn}, 680-1750$ and $30-170 \mathrm{~Bq} \mathrm{~m}^{-3}$ in burrows and creek respectively). From isotope mass balances, a daily water circulation flux through burrows of $30.4 \pm 4.7 \mathrm{~L} \mathrm{~m}^{-2}$ of forest floor is calculated. This study quantifies the underlying physical process, i.e. the tidal flushing of burrows, that supports significant and continuous exports of soluble organic and inorganic matter from mangrove forest floors to the coastal ocean. The potential significance of the circulation flux estimate is illustrated by up-scaling of the forest-scale estimates to the mangrove forests in the entire central Great Barrier Reef. This extrapolation indicates that the annual water flux circulated by this tidally-driven 'mangrove pump' is equivalent to as much as $20 \%(16-22 \%)$ of the total annual river discharge along the ca. $400 \mathrm{~km}$ long coastline of this region.
\end{abstract}

(c) 2012 Elsevier Ltd. All rights reserved.

\section{INTRODUCTION}

Mangrove forests are the dominant intertidal vegetation of the tropics. They are highly productive and contribute significantly to near-shore biogeochemical solute budgets (Scully et al., 2004; Dittmar et al., 2006; Bouillon et al., 2008). It is well established that outwelling from mangrove forests represents a major source of carbon to the coastal

\footnotetext{
* Corresponding author. Present address: Laboratoire des sciences de l'environnement marin, CNRS UMR 6539, Institut Universitaire Européen de la Mer, Université de Bretagne Occidentale, 29280 Plouzané, France. Tel.: +33 (0)2 98498654.

E-mail address: thomas.stieglitz@jcu.edu.au (T.C. Stieglitz).
}

ocean (Boto and Bunt, 1981; Robertson and Alongi, 1995; Bouillon et al., 2007). Although covering only small portions of the coastlines of the world on a global scale, mangrove ecosystems account for $10 \%$ or more of the terrestrially-derived dissolved organic carbon transported to the ocean (Dittmar et al., 2006).

Tidal inundation of a forest exchanges water and solutes between forest and coastal zone, and tidal amplitude and frequency are important controlling factors in the efficiency of this exchange (Alongi et al., 1989; Ayukai et al., 1998; Dittmar and Lara, 2001). The forest sediments are one of the most productive areas of mangrove ecosystems, and much of the biogeochemical cycling occurs in the subsurface (Alongi, 1994). Burrowing animals, notably sesarmid 
crabs, remove up to $75 \%$ of the total annual litter fall from the forest floor (Robertson and Daniel, 1989). In the subsurface, complex microbial communities rapidly cycle nutrients, carbon, and other compounds (e.g., Boto et al., 1989; Holguin et al. 2001; Bouillon et al., 2008; Kristensen et al., 2008). Given the rapid biogeochemical cycling, the efficient movement of water through the mangrove forest floor is critical (e.g., Smith et al., 1991). Yet accumulation of finegrained sediments in mangrove forests makes typical forest floors highly impermeable, with bulk diffusion coefficients on the order of $10^{-5} \mathrm{~m}^{2}$ day $^{-1}$ (Hollins et al., 2000). Thus, removal of solutes from the subsurface must be a comparatively slow process if the primary mechanism is diffusion into and out of the sediments. Enhancement of bulk hydraulic permeability associated with burrows built by animals such as crabs and other crustaceans can therefore play an important role in the hydrology and biogeochemistry of these sediments (Heron and Ridd, 2003; Kristensen et al., 2008; Smith et al., 2009; Xin et al., 2009).

Whilst tidal range and porewater concentrations are considered primary driving forces of outwelling of nutrients and organic matter from mangrove forests (Dittmar and Lara, 2001), the efficiency of the exchange from the subsurface - where much of the cycling occurs - to tidal surface waters across the forest-floor must also be an important driver of outwelling. In other words, the hydrological pathway for mangrove-derived solutes to enter the coastal zone needs to be considered a two-step process: (1) exchange across forest-floor into overlying water at high tide and (2) subsequent tidal exchange from creek to coastal ocean.

Tidally-driven circulation through burrows with multiple openings created by macro-fauna in mangrove forests occurs as part of this exchange process. The extent of burrow recirculation has previously been estimated on the scale of individual burrows, by monitoring the filling and draining of discrete burrows during the rise and fall of the tide (Ridd, 1996; Stieglitz et al., 2000b). Stieglitz et al. (2000b) estimate that such burrows enhance the effective surface area of mangrove sediment by a factor of seven, greatly enhancing the diffusive solute flux from mangrove sediments. For example, build-up of salt in the root zone as a result of salt-secretion during water uptake by the trees is prevented by diffusion of highly saline water into burrows adjacent to roots, and by the subsequent tidal flushing of the burrows in the otherwise impermeable forest floor (Stieglitz et al., 2000a).

The actual volume of seawater entering the burrows per unit area of forest depends on a number of factors, including the local topography, tidal range and burrow density, and is thus not constant across a forest. While studies of individual burrows have provided valuable constraints on burrow water fluxes, the hydrological efficiency of this exchange process remains poorly understood on forest scale. In order to understand the contributions of this burrowscale exchange process to ecosystem-scale fluxes, in this study, we investigate this process on a whole-of-forest scale, thereby demonstrating that this tidally-driven 'mangrove pump' is an important link in the chain of key hydrological exchange processes in mangrove ecosystems, providing a fundamental link from the sediment to the 'outside world', ultimately contributing significantly to the delivery of ecosystem services of mangroves.

The purpose of this study is not to revisit the biogeochemical cycling in mangrove forests, but to document the primary hydrological connection that facilitates solute exchange from forest floor to creek (and subsequently to the ocean). For this purpose, conservative radiochemical tracer techniques previously established for quantifying submarine groundwater discharge are employed (Burnett et al., 2006). Naturally-occurring isotopes of radon and radium are ideal tracers of groundwater-surface water exchange because their activity in groundwater (in this case, burrow water) is typically greater than in surface water by two orders of magnitude or more (Burnett et al., 2006; Moore, 2010). In this study, fluxes of radon $\left({ }^{222} \mathrm{Rn}\right)$ and three radium isotopes $\left({ }^{223} \mathrm{Ra},{ }^{224} \mathrm{Ra}\right.$ and $\left.{ }^{228} \mathrm{Ra}\right)$ from a mangrove forest floor to a creek were determined using a mass balance approach, allowing an estimation of burrow water fluxes across the forest floor. These radionuclide tracers can be considered conservative proxies for fluxes of other solutes. The implications of this recirculation process on burrow and forest scale are discussed.

\section{METHODS}

\subsection{Study site}

Coral Creek $\left(18.244^{\circ} \mathrm{S}\right.$ and $146.228^{\circ} \mathrm{E}$; Fig. 1) on Hinchinbrook Island on the Great Barrier Reef (GBR) coast is a typical northern Australian mangrove creek (e.g. Wolanski et al., 1980). It is about $7 \mathrm{~km}$ long and experiences semi-diurnal tides with a mean and maximum tidal range of 2.2 and $3.4 \mathrm{~m}$ respectively.

Coral Creek drains a forest dominated by the red mangrove Rhizophora stylosa (Bunt and Bunt, 1999), and, importantly, does not have a riverine head. It thus does not receive any freshwater input - neither by surface nor ground water - except by direct rainfall which generally only occurs during the tropical wet season (January to April), resulting in an inverse salinity gradient during the tropical dry season, which is typical for such 'dry' estuaries (e.g. Wolanski et al., 1980).

The height of the creek bank corresponds to the mean tidal water level. Thus at water levels greater than mean tide the adjacent forests are inundated, and at levels below mean tide water flow is confined to the creek. Sediment in the mangrove forest consists of fine-grained silt and clay particles. The forest floor shows a high density of surface burrow openings, typical of other mangrove forest in the region (Fig. 2). Typically, individual burrows in such Rhizophora dominated forests have a tunnel diameter in the order of 5-10 cm, extend to $>1 \mathrm{~m}$ below the forest floor and have a volume of 60-70 L (Stieglitz et al., 2000b). Within the creek, the sediment is comprised of mainly quartz-rich coarse-grained sand.

Data was collected in April 1997 and in mid-December 2005. The latter sampling occurred during the late dry season prior to wet season rainfall, and was focused on radon $\left({ }^{222} \mathrm{Rn}\right)$ measurement, whereas the 1997 collection was part of a broader regional study measuring the radium isotope 


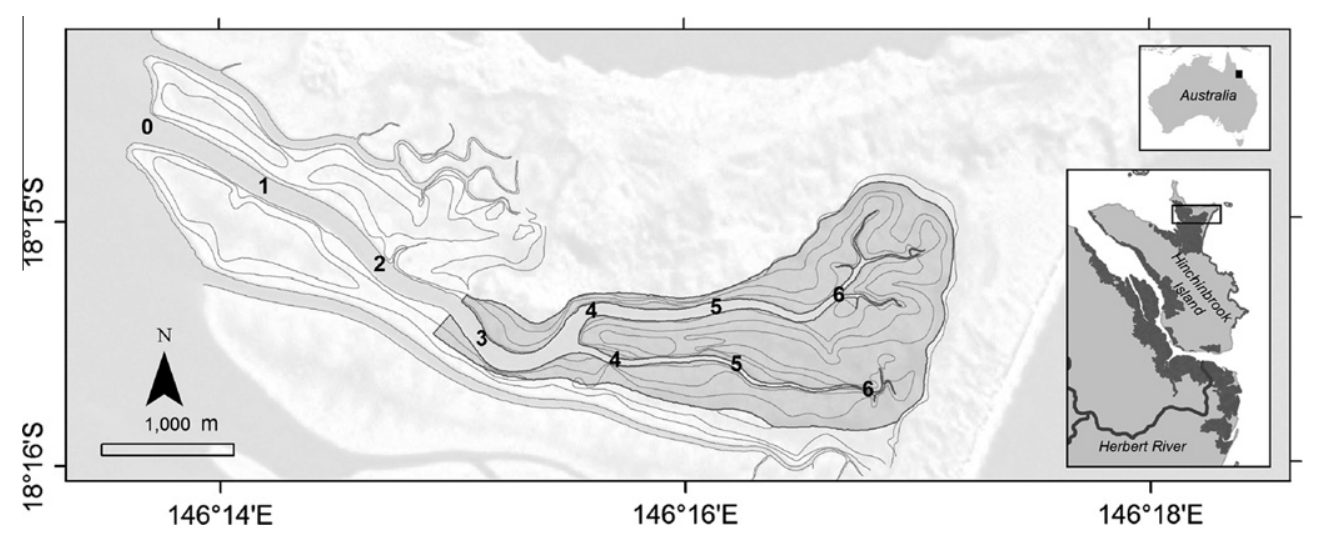

Fig. 1. Location map of Coral Creek. The forest topography contours after Wolanski et al (1980) are shown in $0.5 \mathrm{~m}$ steps. Distance (km) along the creek axis is marked. Note that the creek has no riverine head. Isotope mass balances were constructed for the dark-shaded upstream section of the creek-forest system. The inset maps show the location of Coral Creek on Hinchinbrook Island (dark grey areas are mangrove forests) and its proximity to Hinchinbrook Channel, which lies between the island and mainland and Herbert River.

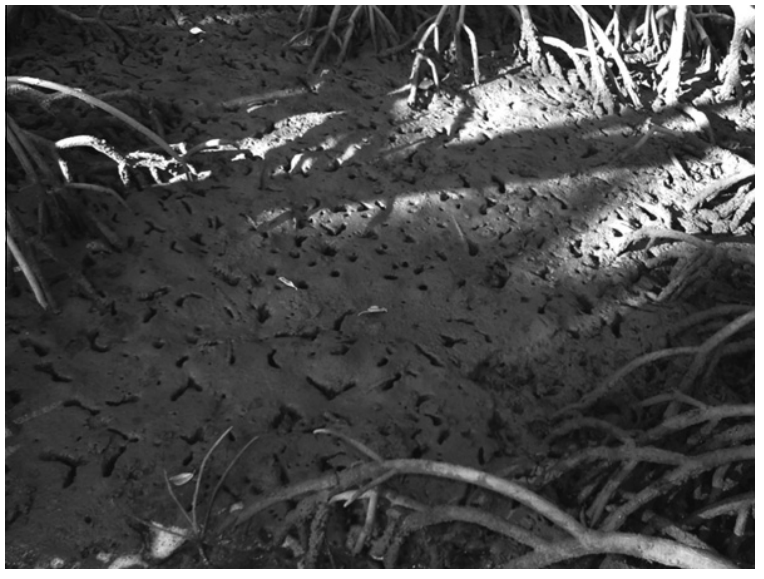

Fig. 2. Openings of animal burrows on the mangrove forest floor. The oblique-angle image shows approximately $5 \times 5 \mathrm{~m}$ of forest floor.

distribution in the adjacent Herbert River estuary and Hinchinbrook channel. Radionuclide activities in burrow and creek water were sampled during both campaigns, and these two data sets represent two independent measures of the radionuclide distribution in the creek at different times. Tidal range during the 1997 and 2005 study was 2.2 and $3.0 \mathrm{~m}$ respectively.

\subsection{Surface water sampling}

${ }^{222} \mathrm{Rn}$ was continuously sampled and counted in situ using three electronic radon-in-air monitors (Durridge RAD-7) in parallel (Stieglitz et al., 2010). Surface water from the mangrove creek was pumped directly through an air-water equilibrator, purging dissolved radon in seawater into air. The ${ }^{222} \mathrm{Rn}$-enriched air was circulated in a closed air-loop, which passes through the monitors, to establish equilibrium between the circulating air and the continuously pumped seawater. The monitors count $\alpha$-decays of ${ }^{222} \mathrm{Rn}$ daughters, and ${ }^{222} \mathrm{Rn}$ activity is determined by discriminating the ${ }^{222} \mathrm{Rn}$-daughter decays in energy-specific windows. The spatial distribution of ${ }^{222} \mathrm{Rn}$ in the creek was recorded by continuously sampling whilst slowly traversing the length of the creek during low tide on 12 December 2005. The boat was driven along a sinuous route that extended across the entire channel width. Laboratory experiments have shown that this radon extraction using in situ equilibration introduces a lag time of $\sim 10 \mathrm{~min}$, which was corrected for by adjusting the time of measurement along the vessel track after Stieglitz et al. (2010). Sampling interval was five minutes, which resulted in a spatial resolution of better than $500 \mathrm{~m}$, depending on boat speed. Concurrently with radon, surface water salinity was recorded at $5 \mathrm{~min}$ intervals. For analysis of radium isotopes, $40 \mathrm{~L}$ samples of creek surface water were collected at 1-2 km intervals along the length of Coral Creek in 1997. In 2005, surface water radium samples were collected concurrently with selected radon samples at different times at one location approximately midway upstream. The 2005 radium data is used to support radon-derived calculations (residence time and gas loss calculations) - it does not represent the radium distribution of the complete creek and thus does not allow for a separate radium mass balance reconstruction in the 2005 data set. One sigma uncertainties based on counting statistics are reported for radionuclide activities.

\subsection{Burrow water sampling}

Burrow (source) water was sampled on 16 December 2005 by first locating burrow chambers at approximately 30 and $70 \mathrm{~cm}$ depth below the forest floor with a geoelectric sensor after Stieglitz et al. (2000a), then installing mini-piezometers $(100 \mathrm{~cm}$ long stainless steel tubes with a diameter of $0.6 \mathrm{~cm}$, and with small perforations at the bottom end) in the burrow chambers. At the time of sampling (ca. $1 \mathrm{~h}$ prior to tidal inundation), the water level in the burrows was $15-20 \mathrm{~cm}$ below the sediment surface. In order to avoid gas loss during sampling for radon, a two-syringe setup was used, whereby one syringe $(100 \mathrm{ml})$ was used to slowly and continuously draw water from the burrow, while the 
second syringe $(30 \mathrm{ml})$ was used to collect the sample from the flushed piezometer. This was accomplished by attaching a needle to the small syringe and inserting the needle through a piece of tubing that connected the large syringe to the top of the piezometer. After flushing the piezometer and syringe, ca. $30 \mathrm{ml}$ of burrow water was collected in the small syringe and then transferred through a filter into a $25 \mathrm{ml}$ vial that contained about $10 \mathrm{ml}$ of an oil-based scintillant for ${ }^{222} \mathrm{Rn}$ analysis. The vial was sealed, and the ${ }^{222} \mathrm{Rn}$ activity was determined by liquid scintillation counting at CSIRO Land and Water, Adelaide (Cook et al., 2003).

In 1997 water draining slowly from burrows in the creek banks during low tide was collected for radium analysis. One sample each was collected from the Coral Creek forest and the nearby Herbert River mangrove forest respectively. In 2005, radium burrow water samples were collected concurrently with the radon samples by slowly drawing water from the burrows with $100 \mathrm{ml}$ syringes until a total of $1 \mathrm{~L}$ was collected. Radium was extracted from the water samples using the procedures detailed below.

\subsection{Radium analysis}

Radium isotopes were extracted from all samples by slowly passing filtered water through $\mathrm{MnO}_{2}$-coated acrylic fibres (Mn-fibre), which adsorb and collect the dissolved radium (Moore, 1976). Samples of burrow water collected in 2005 from similar depths were combined to increase sample volume and to improve radium isotope count rates. For samples collected in 1997, the activities of the short-lived isotopes, ${ }^{223} \mathrm{Ra}$ and ${ }^{224} \mathrm{Ra}$, were measured on the ship within $12 \mathrm{~h}$ of collection using a counting system ( $\mathrm{RaDeCC}$ ) consisting of photomultiplier tubes and delayed coincidence circuit for the identification of the short-lived radon daughters, ${ }^{219} \mathrm{Rn}$ and ${ }^{220} \mathrm{Rn}$ (Moore and Arnold, 1996). Samples collected in 2005 (surface and burrow water) were measured using a similar system at CSIRO Canberra 2-3 days after sample collection. The Mn-fibre samples were partially dried, and placed in a closed-loop air circulation system connected to the counters. Supported ${ }^{224} \mathrm{Ra}$ and ${ }^{223} \mathrm{Ra}$ activity, corresponding to the water concentrations of ${ }^{228} \mathrm{Th}$ and ${ }^{227} \mathrm{Ac}$, was obtained by re-measuring the fibre samples three weeks after sample collection. These supported concentration were found to be insignificant, being $<1 \%$ of the total ${ }^{224} \mathrm{Ra}$ and ${ }^{223} \mathrm{Ra}$ water concentrations.

After measurement of short-lives isotopes was completed, the Mn-fibre was ashed at $400{ }^{\circ} \mathrm{C}$ and the activities of the long-lived isotopes, ${ }^{226} \mathrm{Ra}$ (used for radon in-growth corrections for the 2005 collection) and ${ }^{228} \mathrm{Ra}$, were determined by $\gamma$-ray spectrometry following the methods of Murray et al. (1987). All radium isotope measurements were corrected for radioactive decay, and activities quoted pertain to the time of sample collection.

\subsection{Creek bathymetry and forest topography}

The creek bathymetry was recorded with a vesselmounted echosounder and GPS recorder. Raw depth data was corrected for tidal variations as measured by tide gauges installed at the mouth and close to the head of the creek during the surveys. Cross-sections of the creek were extracted, and creek volume was calculated by multiplying its surface area with its average depth. The original raw data of an extensive topographic survey of the Coral Creek mangrove forest as reported in Wolanski et al. (1980) was digitally reprocessed and used to calculate inundation areas at different tidal water levels. The uncertainty of volume and area calculation is estimated at $5 \%$.

\subsection{Radon and radium mass balances}

Individual mass balances for each of the four isotopes ${ }^{222} \mathrm{Rn},{ }^{223} \mathrm{Ra},{ }^{224} \mathrm{Ra}$ and ${ }^{228} \mathrm{Ra}$ were constructed, using methods similar to those described in Hancock et al. (2000) and Crusius et al. (2005). Assuming steady-state, the source of each isotope must be balanced by its loss. $\mathrm{Ra}$ and $\mathrm{Rn}$ produced in the sediment by radioactive decay of the parent nuclide accumulate in the dissolved form in sediment pore water, subsequently migrating across the sediment-water interface. In the absence of hydraulic heads associated with fresh, terrestrial groundwater (as is the case in Coral Creek), two distinct processes of tracer migration need to be considered: (a) diffusion of $\mathrm{Ra}$ and $\mathrm{Rn}$ from surface sediment layers of the forest floor into overlying surface water during periods of forest inundation and (b) migration across the burrow wall into burrow water (also by diffusion), and subsequent tidal flushing of burrows. Thus two distinct source terms are calculated: (a) the Ra and $\mathrm{Rn}$ diffusive flux from the forest floor and (b) export of $\mathrm{Ra}$ and $\mathrm{Rn}$ from burrows by tidally-induced flushing.

The sandy quartz-rich sediment of the creek bed contains low activities of thorium isotopes (the parents of the studied radionuclides) with activities of $4-6 \mathrm{~Bq} \mathrm{~kg}^{-1}$ being measured in similar near-shore sediment collected in the region (Hancock et al., 2006). This is approximately one order of magnitude lower than the activity of the mangrove sediment. Given the low capacity of this creek sediment to generate $\mathrm{Ra}$ and $\mathrm{Rn}$, together with the comparatively small surface area of the creek $(<15 \%$ of the creek drainage area), the flux of $\mathrm{Ra}$ and ${ }^{222} \mathrm{Rn}$ from the creek bed is assumed to be negligible. Therefore, in calculating the diffusive flux from sediment only the forest floor sediments is considered.

$\mathrm{Ra}$ and $\mathrm{Rn}$ are lost from the system by radioactive decay, atmospheric evasion $\left({ }^{222} \mathrm{Rn}\right.$ only), and tidal mixing with downstream water masses. Thus the mass balance for the creek system is

$Q_{\text {bur }}\left(C_{\text {bur }}-C_{c r}\right)+F_{\text {diff }}=C_{c r} V(\lambda+k)+J_{\text {long }}$

where $Q_{b u r}\left(\mathrm{~m}^{3} \mathrm{day}^{-1}\right)$ is the water flux across the forest floor, $F_{\text {diff }}\left(\mathrm{Bq} \mathrm{day}^{-1}\right)$ is the total flux of diffusion flux of each radionuclide ( $\mathrm{Ra}$ and $\mathrm{Rn}$ ) as a result of diffusion from the forest floor, $C_{b u r}\left(\mathrm{~Bq} \mathrm{~m}^{-3}\right)$ the radionuclide activity in the burrow (source) water, $C_{c r}$ is the mean unsupported activity in the upstream section of the creek (see below), $V$ is the low tide volume, $\lambda$ is the decay constant, $k$ is the re-aeration coefficient for gas loss of radon to the atmosphere, and $J_{\text {long }}$ is the longitudinal mixing loss from the creek, as illustrated in Fig. 3. The mass balance equation for each of the individual radium isotopes is the same as 


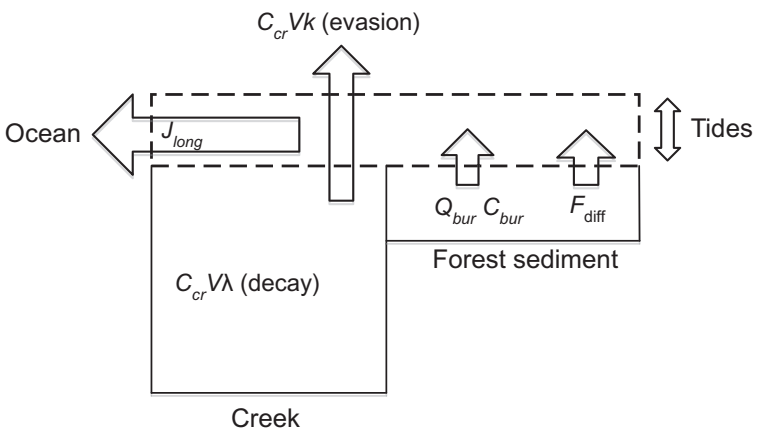

Fig. 3. Conceptual box model illustrating the fluxes considered in the mass balance calculations.

for radon, except that radium is not lost to the atmosphere and therefore $k$ in Eq. (1) is zero. Below, the calculation of each parameter in the mass balance equation is described in detail, beginning with the loss terms.

\subsubsection{Atmospheric radon loss}

A two-tracer approach is used to directly determine the gas loss from the upper reach of the creek-forest system (e.g. Dulaiova and Burnett, 2006). Radium is not lost to the atmosphere, and therefore the loss of radon can be calculated from activity ratios of concurrently collected samples of radon and radium:

$\frac{A_{\mathrm{Rn}}}{A_{\mathrm{Ra}}}=\frac{A_{\mathrm{Rn}}^{0}}{A_{\mathrm{Ra}}^{0}} \exp \left(\left(\lambda_{\mathrm{Ra}}-\lambda_{\mathrm{Rn}}-k\right) t\right)$

where $A$ and $A^{0}$ is the creek and burrow activities respectively for radon and radium, $\lambda$ is the respective decay constant, $k$ is the re-aeration coefficient, and $t$ is the mean residence time in the creek. The value of $t$ can be estimated by calculating the decay of the short-lived ${ }^{224} \mathrm{Ra}$ isotope relative the longer-lived ${ }^{228} \mathrm{Ra}$ isotope during transport from its source (burrow water) to the creek. The assumption of a burrow water source is reasonable given that this is where the highest ${ }^{224} \mathrm{Ra} /{ }^{228} \mathrm{Ra}$ ratio is found. Using the ${ }^{224} \mathrm{Ra}$ and ${ }^{228} \mathrm{Ra}$ pair

$\frac{A_{224}}{A_{228}}=\frac{A_{224}^{0}}{A_{228}^{0}} \exp \left(\left(\lambda_{228}-\lambda_{224}\right) t\right)$

where $A$ and $A^{0}$ are the creek and burrow activities and $\lambda$ is the radium isotope decay for the different radium isotopes (identified by subscripts). From this equation, the mean residence time $t$ can be calculated directly. The uncertainty associated with the estimation of $k$ is determined by propagation of uncertainties associated with the measured parameters $t$ and the respective activity ratios.

\subsubsection{Tidal mixing loss}

The tidal mixing loss $J_{\text {long }}$ of a solute from a mangrovefringed tidal creek can be expressed as an apparent longitudinal diffusion term

$J_{\text {long }}=K \frac{\Delta C}{\Delta x}$

where $J_{\text {long }}$ is the downstream mixing loss of a solute with the concentration gradient $\Delta C / \Delta x$ (Ridd et al., 1990). The tidally-averaged apparent diffusion coefficient $K$, has been calculated for Coral Creek by Ridd et al. (1990) to be $10.0 \pm 1.5 \mathrm{~m}^{2} \mathrm{~s}^{-1}$ approximately halfway along Coral Creek. Note that this apparent diffusion approach is valid only for the upstream section of a creek (Ridd et al., 1990). The uncertainty of $J_{\text {long }}$ is determined by propagation of the uncertainty in the measured concentration gradient.

\subsubsection{Diffusive flux from forest sediment during tidal inundation}

Following methods by Hancock et al. (2000), the areal diffusive flux of ${ }^{224} \mathrm{Ra},{ }^{223} \mathrm{Ra}$ and ${ }^{228} \mathrm{Ra}$ during forest inundation is determined by modelling the distribution of ion-exchangeable $\mathrm{Ra}$ in the sediment column with a onedimensional transport equation. Assuming steady state, the diffusive $\mathrm{Ra}$ flux $f_{d}\left(\mathrm{~Bq} \mathrm{~m}^{-2} \mathrm{day}^{-1}\right)$ across the sediment-water interface is approximated by:

$f_{d}=\left(c_{e}-c_{c r}\right) \sqrt{\lambda \Theta D_{s}}$

(Hancock et al., 2000), where $D_{s}$ is molecular diffusion coefficient of $\mathrm{Ra}$ in sediment pore-water, $\Theta$ is a ratio that reflects the fraction of total ion-exchangeable $\mathrm{Ra}$ in the pore water that exists in the dissolved form, $c_{e}$ is the equilibrium ion-exchangeable Ra concentration per unit volume of wet sediment produced in the sediment by the decay of sediment-bound Th isotopes, and $c_{c r}$ is the creek activity. $D_{s}$ is derived from the molecular diffusion coefficient in seawater, which is $7.6 \times 10^{-6} \mathrm{~m}^{-2} \mathrm{day}^{-1}$ at $25^{\circ} \mathrm{C}(\mathrm{Li}$ and Gregory, 1974) and is determined by dividing the seawater coefficient by the square of the sediment tortuosity (Boudreau, 1996).

In deriving $f_{d}$ for this study, measurements made by Hancock et al. (2006) were used, who estimated Ra diffusive fluxes from similar near-shore bottom sediments in nearby regions of the Great Barrier Reef Lagoon. Measurements of sediment porosity (0.73) and $\mathrm{Ra}$ and Th isotope concentrations (Table 1) were made on a combined surface sediment sample collected from representative locations in the Coral Creek mangrove tidal zone and found to be similar (within $\pm 15 \%$ ) to values measured in near-shore sediment samples reported by Hancock et al. (2006). It is therefore assumed that other parameters needed for the calculation of $f_{d}\left(\Theta\right.$ and $\left.c_{e}\right)$ are also similar, and diffusive fluxes are calculated accordingly.

For ${ }^{222} \mathrm{Rn}, f_{d}$ is estimated using the same procedure as for Ra except that $\Theta=1$ in Eq. (2); i.e. all the ${ }^{222} \mathrm{Rn}$ released from the sediment is dissolved. A ${ }^{222} \mathrm{Rn}$ diffusion coefficient of $1.1 \times 10^{-4} \mathrm{~m}^{-2}$ day $^{-1}$ is used (derived from data in Jähne et al. (1987)). The value of $c_{e}$ is estimated by measurement of dissolved ${ }^{222} \mathrm{Rn}$ purged from a slurry of mangrove sediment previously equilibrated for 21 days

Table 1

Radionuclide activities in Coral Creek sediments.

\begin{tabular}{lllll}
\hline${ }^{226} \mathrm{Ra}$ & ${ }^{228} \mathrm{Ra}^{228} \mathrm{Th}$ & ${ }^{230} \mathrm{Th}^{232} \mathrm{Th}$ \\
$\mathrm{Bq} \mathrm{kg}^{-1}$ & $\mathrm{~Bq} \mathrm{~kg}^{-1}$ & $\mathrm{~Bq} \mathrm{~kg}^{-1}$ & $\mathrm{~Bq} \mathrm{~kg}^{-1}$ & $\mathrm{~Bq} \mathrm{~kg}^{-1}$ \\
\hline $21.2 \pm 0.3$ & $34.8 \pm 0.26$ & $35.8 \pm 0.6$ & $29.9 \pm 0.4$ & $51.8 \pm 0.9$ \\
\hline
\end{tabular}


in a sealed glass container, as described by Berelson et al. (1987). Values of $f_{d}$ for $\mathrm{Ra}$ isotopes and ${ }^{222} \mathrm{Rn}$ are given in Table 4. Uncertainties associated with the estimation of $f_{d}$ are determined by propagation of uncertainties associated with the measurement of sediment source terms $\left(c_{e}, c_{c r}\right)$ and that of $\Theta$.

\subsubsection{Source activity}

Unlike the typical case of groundwater discharge to surface water, where groundwater directly enters the receiving water body, in this case the source water activity has to be corrected for the small but non-negligible loss of activity due to gas loss (for radon only) and decay during the period of inundation of the forest (i.e. for the time it takes for the burrow water to enter the creek). Thus the corrected source activity is

$C_{\text {bur }}=C_{\text {bur } / \text { meas }} e^{-(\lambda+k) * i}$

where $C_{\text {bur/meas }}$ is the measured burrow activity, and $i$ is the time during which the forest is inundated $(k=0$ for radium isotopes). If the entire forest was inundated for the entire time of the high tide portion of the tidal cycle, $i$ would be 0.5 days. Here, $i$ is set at 0.3 days to account for the average inundation time of the forest (as determined by the integral of a typical tidal curve).

\section{RESULTS}

\subsection{Creek and burrow water}

Radon and radium activities in the creek increased monotonically with distance from the mouth, indicating a supply of radon and radium from the forest being diluted as a result of mixing with low-activity ocean water (Fig. 4). The low Rn and Ra values observed close to the mouth of the creek were typical for coastal waters in the GBR lagoon (Stieglitz, 2005; Hancock et al., 2006). The salinity distribution in 2005 shows an increase inland from the creek mouth (Fig. 4b). This behaviour is typical of inverse estuaries, which form at the absence of freshwater input during the dry season when evapotranspiration in mangrove forests exceeds tidal flushing (Wolanski et al., 1980; Ridd and Stieglitz, 2002).

Radionuclide activities in animal burrows showed little difference between burrows, but were generally greater in deeper parts of the burrows, indicating an incomplete flushing of the burrows (Table 2). Radium isotope activities of mangrove forest drainage water collected in 1997 are within the range of activities of burrow water samples collected in 2005 for all radium isotopes (Table 2) indicating relative constancy of the burrow source term.

In order to calculate atmospheric loss of ${ }^{222} \mathrm{Rn}$ (Section 3.2.1), radon and radium isotope activities were collected concurrently from the creek in 2005 (Table 2, bottom section). ${ }^{226} \mathrm{Ra}$ activity sampled concurrently was on average $2.1 \pm 0.2 \mathrm{~Bq} \mathrm{~m}^{-3}$ (not included in Table 2). This value was used to correct ${ }^{222} \mathrm{Rn}$ activity in the creek for inwater production from ${ }^{226} \mathrm{Ra}$ decay.

\subsection{Isotope mass balances}

Radon and radium mass balances are constructed for the upstream section of the creek (dashed line in Figs. 1 and 4). This way, the mixing loss of $\mathrm{Ra}$ and $\mathrm{Rn}$ can be derived from an apparent diffusion approach after Ridd et al. (1990), which is valid for the upstream section of a creek
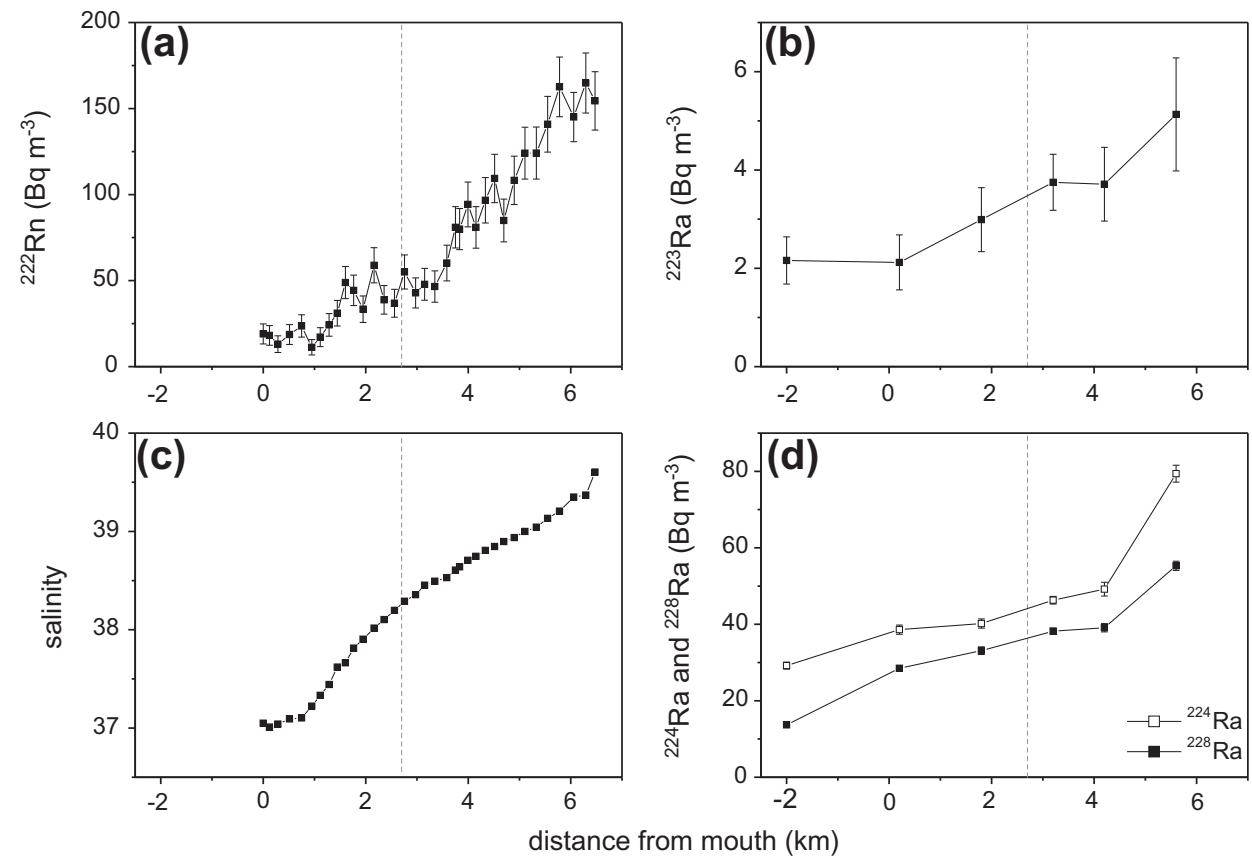

Fig. 4. Radionuclide and salinity transects in Coral Creek. Radon (a) and salinity (c) data was collected in 2005 and radium data (b + d) was collected in 1997. Distance on the $x$-axis corresponds to the locations marked in Fig. 1. The dashed vertical line indicates the location upstream of which the isotope mass balance was constructed (corresponding to the grey area in Fig. 1). 
Table 2

Radionuclide activities in mangrove forest drainage water collected in 1997 (HRE \& CC) and burrow water (burrows 1-4) collected in 2005. Radium burrow samples from similar depths were combined to improve counting efficiencies. Burrow depths refer to the vertical depth below the forest floor from which the water sample was recovered. The bottom part of the table shows radionuclide activities measured during a $12 \mathrm{~h}$ time series on 13 December 2005 in creek water at one location approximately midway upstream. Collection time is in indicated. This data is used for the calculation of atmospheric loss of radon in Section 3.2.1.

\begin{tabular}{|c|c|c|c|c|c|c|c|c|c|}
\hline \multirow[t]{2}{*}{ Sample } & \multirow{2}{*}{$\begin{array}{l}\text { Depth } \\
\mathrm{cm}\end{array}$} & \multicolumn{2}{|l|}{${ }^{222} \mathrm{Rn}$} & \multicolumn{2}{|l|}{${ }^{223} \mathrm{Ra}$} & \multicolumn{2}{|l|}{${ }^{224} \mathrm{Ra}$} & \multicolumn{2}{|l|}{${ }^{228} \mathrm{Ra}$} \\
\hline & & $\mathrm{Bq} \mathrm{m}^{-3}$ & $\pm 1 \sigma$ & $\mathrm{Bq} \mathrm{m}^{-3}$ & $\pm 1 \sigma$ & $\mathrm{Bq} \mathrm{m}^{-3}$ & $\pm 1 \sigma$ & $\mathrm{Bq} \mathrm{m}^{-3}$ & $\pm 1 \sigma$ \\
\hline HRE & & & & 12.8 & 2.8 & 257 & 6 & 107.1 & 2.6 \\
\hline $\mathrm{CC}$ & & & & 9.4 & 1.8 & 214 & 3 & 90.2 & 1.9 \\
\hline Burrow 1 & 30 & 760 & 90 & 8.7 & 1.1 & 189 & 8 & 60 & 2.4 \\
\hline Burrow 2 & 30 & 680 & 80 & 8.7 & 1.1 & 189 & 8 & 60 & 2.4 \\
\hline Burrow 3 & 30 & 1310 & 120 & 5.9 & 0.9 & 177 & 5 & 61.4 & 2.7 \\
\hline Burrow 4 & 25 & 1140 & 120 & 5.9 & 0.9 & 177 & 5 & 61.4 & 2.7 \\
\hline Burrow 1 & 70 & 1240 & 110 & 12 & 1.7 & 215 & 7 & 78.8 & 4.1 \\
\hline Burrow 2 & 70 & 1140 & 110 & 13.6 & 1.6 & 234 & 7 & 83.5 & 3.8 \\
\hline Burrow 3 & 65 & 1540 & 130 & 12 & 1.7 & 215 & 7 & 78.8 & 4.1 \\
\hline Burrow 4 & 70 & 1750 & 140 & 13.6 & 1.6 & 234 & 7 & 83.5 & 3.8 \\
\hline Creek $1(02: 00)$ & & 109.5 & 14.0 & 5.3 & 0.3 & 47.5 & 1.2 & 44.3 & 0.7 \\
\hline Creek $2(03: 50)$ & & 102.4 & 12.9 & 4.3 & 0.2 & 42.5 & 1.1 & 35.9 & 0.1 \\
\hline Creek 3 (05:30) & & 89.25 & 12.4 & 2.5 & 0.2 & 33.6 & 0.6 & 30.8 & 0.6 \\
\hline Creek 4 (07:00) & & 65.6 & 10.9 & 2.3 & 0.1 & 31.2 & 0.5 & 20.7 & 0.4 \\
\hline Creek $5(08: 30)$ & & 55.75 & 8.7 & 1.2 & 0.1 & 15.4 & 0.7 & 9.7 & 0.3 \\
\hline Creek $6(10: 00)$ & & 91.1 & 13.0 & 3.8 & 0.2 & 34.8 & 1.0 & 27.4 & 0.5 \\
\hline Creek 7 (11:30) & & 95.8 & 12.9 & 4.4 & 0.3 & 51.5 & 1.3 & 33.5 & 0.7 \\
\hline Creek 8 (13:30) & & 103.8 & 13.7 & 4.3 & 0.2 & 48.0 & 1.6 & 31.2 & 0.6 \\
\hline
\end{tabular}

Table 3

Summary of radon gas loss calculations. The columns 'burrows' and 'creek' contain the mean activity ratios of the respective radionuclides (as calculated from values in Table 1). $t$ is the radium mean residence time, and $k$ is the re-aeration coefficient. The bottom row includes an alternative empirical calculation for comparison.

\begin{tabular}{lllll}
\hline Method & Burrows & Creek & $t$ (day) & $k\left(\right.$ day $\left.^{-1}\right)$ \\
\hline${ }^{224} \mathrm{Ra} /{ }^{228} \mathrm{Ra}$ & $3.0 \pm 0.2$ & $1.3 \pm 0.1$ & $4.2 \pm 0.2$ & - \\
${ }^{222} \mathrm{Rn} /{ }^{224} \mathrm{Ra}$ & $5.3 \pm 0.6$ & $2.5 \pm 0.3$ & $4.2 \pm 0.2^{\mathrm{a}}$ & $0.190 \pm 0.051$ \\
${ }^{222} \mathrm{Rn} /{ }^{228} \mathrm{Ra}$ & $16 \pm 1.8$ & $3.3 \pm 0.4$ & $4.2 \pm 0.2^{\mathrm{a}}$ & $0.189 \pm 0.034$ \\
${\text { Clark et al. }(1995)^{\mathrm{b}}}$ & & & & $0.197 \pm 0.300$ \\
\hline
\end{tabular}

${ }^{\mathrm{a}}$ The mean residence time was calculated with the isotope pair ${ }^{224} \mathrm{Ra}$ and ${ }^{228} \mathrm{Ra}$ and used to calculate the gas transfer parameters.

${ }^{\mathrm{b}}$ Calculated from empirical relationship of gas transfer and wind after Clark et al. (1995), using the estimated mean wind speed of $1.5 \pm 0.5 \mathrm{~m} \mathrm{~s}^{-1}$.

only (see Section 2.6.2). The loss terms of atmospheric evasion and tidal mixing and source terms of forest floor diffusion and burrow water are quantified first; subsequently, the mass balance is constructed.

\subsubsection{Atmospheric loss}

Using Eq. (3) and the mean activity ratios from the burrows and the creek (Table 2) for $A^{0}$ and $A$ respectively, the mean residence time in the creek was calculated to be $4.2 \pm 0.2$ days (Table 3 ). Using mean activity ratios, re-aeration coefficients were determined from Eq. (2) to be 0.190 and $0.189 \mathrm{day}^{-1}$ using ${ }^{222} \mathrm{Rn} /{ }^{224} \mathrm{Ra}$ and ${ }^{222} \mathrm{Rn} /{ }^{228} \mathrm{Ra}$, respectively (Table 3 ). By using the activity ratios of the source (burrows) and the sink (creek), the calculated re-aeration coefficient $k$ is representative for the whole-of-system loss and accounts for any radon gas loss that may have occurred within the forest as well as within the creek. The re- sults indicate that loss of $\mathrm{Rn}$ by atmospheric evasion is very similar to the loss of ${ }^{222} \mathrm{Rn}$ by radioactive decay, where $\lambda=0.181 \mathrm{day}^{-1}$. It can be shown that this re-aeration coefficient obtained with the two-tracer method is similar to that calculated from empirical relationships based on gas transfer velocity and wind speed, where surface turbulence and gas transfer is forced by both wind and tidal currents. Following Clark et al. (1995), at an estimated wind speed of $1.5 \pm 0.5 \mathrm{~m} \mathrm{~s}^{-1}$ (a reasonable estimate for mean wind speed based on field observations) $k=0.197 \pm 0.300$ day $^{-1}$ is calculated.

\subsubsection{Tidal mixing loss}

The tidal mixing loss can be calculated from the longitudinal distribution of the tracers (Fig. 4). The longitudinal gradient of radon activity is determined to be $40 \mathrm{~m} \mathrm{~Bq} \mathrm{~L}^{-1} \mathrm{~km}^{-1}$ in the upstream section (dashed line in Fig. 4a). From Eq. (4) 
Table 4

Radium (1997) and radon (2005) isotope mass balance parameters for the forest-creek system. Water flux was calculated using Eq. (1).

\begin{tabular}{|c|c|c|c|c|}
\hline & ${ }^{223} \mathrm{Ra}$ & ${ }^{224} \mathrm{Ra}$ & ${ }^{228} \mathrm{Ra}$ & ${ }^{222} \mathrm{Rn}$ \\
\hline$\overline{\lambda\left(\mathrm{day}^{-1}\right)}$ & 0.059 & 0.190 & 0.0003 & 0.181 \\
\hline$k\left(\right.$ day $\left.^{-1}\right)$ & 0 & 0 & 0 & $0.189 \pm 0.034$ \\
\hline$V\left(\mathrm{~m}^{3}\right)$ & $(1.28 \pm 0.06) 10^{6}$ & $(1.28 \pm 0.06) 10^{6}$ & $(1.28 \pm 0.06) 10^{6}$ & $(1.39 \pm 0.07) 10^{6}$ \\
\hline$C_{c r}\left(\mathrm{~Bq} \mathrm{~m}^{-3}\right)$ & $4.0 \pm 0.4$ & $53.7 \pm 0.8$ & $41.9 \pm 0.6$ & $119 \pm 3$ \\
\hline$C_{\text {bur } / \text { meas }}\left(\mathrm{Bq} \mathrm{m}^{-3}\right)$ & $11.1 \pm 1.7$ & $235.5 \pm 21.5$ & $98.7 \pm 8.5$ & $973 \pm 52$ \\
\hline$C_{b u r}\left(\mathrm{~Bq} \mathrm{~m}^{-3}\right)$ & $10.9 \pm 1.7$ & $222.1 \pm 20.2$ & $98.6 \pm 8.5$ & $870 \pm 46$ \\
\hline$f_{d}\left(\mathrm{~Bq} \mathrm{~m}^{-2} \mathrm{day}^{-1}\right)$ & $0.112 \pm 0.017$ & $2.52 \pm 0.38$ & $0.390 \pm 0.058$ & $13.1 \pm 2.0$ \\
\hline$F_{\text {diff }}\left(\mathrm{Bq}\right.$ day $\left.^{-1}\right)$ & $(1.01 \pm 0.15) 10^{5}$ & $(2.26 \pm 0.34) 10^{6}$ & $(3.50 \pm 0.53) 10^{5}$ & $(1.21 \pm 0.18) 10^{7}$ \\
\hline$Q_{b u r}\left(\mathrm{~m}^{3}\right.$ day $\left.^{-1}\right)$ & $(8.43 \pm 4.01) 10^{4}$ & $(1.12 \pm 0.16) 10^{5}$ & $(8.08 \pm 1.58) 10^{4}$ & $(9.00 \pm 1.17) 10^{4}$ \\
\hline$A_{\text {forest }}\left(\mathrm{m}^{2}\right)$ & $(3.00 \pm 0.15) 10^{6}$ & $(3.00 \pm 0.15) 10^{6}$ & $(3.00 \pm 0.15) 10^{6}$ & $(3.07 \pm 0.15) 10^{6}$ \\
\hline Water flux $\left(\mathrm{L} \mathrm{m}^{-2} \mathrm{day}^{-1}\right)$ & $28.1 \pm 13.4$ & $37.3 \pm 5.7$ & $27.0 \pm 5.5$ & $29.3 \pm 4.1$ \\
\hline
\end{tabular}

the tidal mixing loss from the upstream section of the creek is therefore $2.76 \times 10^{7} \mathrm{~Bq} \mathrm{day}^{-1}$, using an apparent diffusion coefficient $K=10 \mathrm{~m}^{2} \mathrm{~s}^{-1}$ as derived for this creek by Ridd et al. (1990). Similarly, values for tidal loss of radium are determined from the 1997 transects (Fig. 4b and d; Table 4). It is interesting to note, that the value for the apparent diffusion coefficient $K=10 \mathrm{~m}^{2} \mathrm{~s}^{-1}$ as derived by Ridd et al. (1990) which is used here can be verified independently by considering the salinity gradient measured in the upstream section of Coral Creek in 2005 (Fig. 4). The creek has an inverse salinity distribution as a result of a lack of freshwater input to the creek during the dry season and loss of water due to evapotranspiration (Wolanski et al., 1980; Ridd and Stieglitz, 2002). In steady state, the loss of salt by mixing to the lower-salinity offshore waters must be balanced by the increase in salt concentration due to this evapotranspiration, and an evapotranspiration rate required to balance the loss of salt due to mixing is calculated to be $1.6 \mathrm{~mm} \mathrm{day}^{-1}$. This value is consistent with previously modelled estimates for a close-canopy mangrove forest (e.g. Ridd and Stieglitz, 2002), indicating that $K=10 \mathrm{~m}^{2} \mathrm{~s}^{-1}$ adequately describes solute mixing loss.

\subsubsection{Forest floor diffusive flux}

The calculated values of $f_{d}$ for Ra isotopes and ${ }^{222} \mathrm{Rn}$ are presented in Table 4 . The $f_{d}$ values for Ra isotopes are similar to those calculated and measured in fine-grained nearshore and estuarine sediment by Hancock et al. (2000, 2006) and in other locations (summarized by Moore (2007)). Notably, the ${ }^{222} \mathrm{Rn} /{ }^{224} \mathrm{Ra}$ activity ratio of diffusive fluxes calculated here (4.5) is similar to that measured in the burrows (5.3, Table 3), indicating that the relative magnitude of the diffusive flux estimates for these tracers is correct. The value of $f_{d}$ is multiplied with the inundated forest surface area and the inundation factor $i$ (see Section 2.6.4) to give the total diffusive flux of $\mathrm{Ra}$ and $\mathrm{Rn}$ emanating from the forest floor, $F_{\text {diff }}$ (units Bq day ${ }^{-1}$; Table 4).

\subsubsection{Source activity}

In the radium mass balance calculations, water draining from burrows in the creek wall collected during the same campaign as surface water (1997) is used as source activity. For the radon mass balance, the mean activities in the upper parts of the burrows measured in 2005 is considered an appropriate source term: the observed systematic radionuclide activity gradients with depth in the burrows as evident from Table 2 indicate that the burrows are not completely flushed. This suggests that the radon activity in the upper burrow parts is a more representative characterization of the source term, rather than the often applied approach in mass balance calculations of indiscriminately averaging all source activity measurements.

\subsubsection{Isotope mass balance results}

The results of the isotope mass balance estimates, together with the parameters used, are summarized in Table 4. Mean measured unsupported creek water activity $C_{c k}$ (weighted by creek cross section) was extracted from the recorded transects (Fig. 4); $V$ was calculated from the creek surface area and mean depth at low tide at time of sampling (as determined from bathymetry survey), and subsequently $Q_{\text {bur }}$ was calculated using Eq. (1). Finally, the area of forest floor $A_{\text {forest }}$ at high tide level was determined from the forest topographic data (different in 1997 and 2005 due to different tidal ranges at the time of sampling), and the average water flux across the forest floor per unit area was obtained by dividing the total flux $Q_{b u r}$ by the inundated forest area $A_{\text {forest }}$. The measured activity ratios of radon in creek and burrow water are considered to be the greatest source of error in the mass balance calculations (Eq. (1)). Therefore, throughout the calculation of the water flux, the uncertainties in water flux are estimated by propagating these major uncertainties of creek and source water estimates.

The resulting water flux estimates are $29.3 \pm 4.1$, $28.1 \pm 13.4, \quad 37.3 \pm 5.7$ and $27.0 \pm 5.5 \mathrm{~L} \mathrm{~m}^{-2} \mathrm{day}^{-1}$ for, respectively, ${ }^{222} \mathrm{Rn}(2005),{ }^{223} \mathrm{Ra},{ }^{224} \mathrm{Ra}$, and ${ }^{228} \mathrm{Ra}(1997)$. Overall, the results obtained during two independent field studies in 1997 and 2005 are consistent with each other. The mean water flux and its standard deviation of $30.4 \pm 4.7 \mathrm{~L} \mathrm{~m}^{-2}$ day $^{-1}$ is considered a robust estimate of the flushing process.

It is interesting to note that the loss terms of radioactive decay, atmospheric evasion, and tidal mixing make approximately equal contributions to the overall radon loss from the system, i.e. one-third each. Overall, diffusion constitutes only a minor fraction of the total radionuclide flux, ranging from $7 \%$ of the total flux for ${ }^{228} \mathrm{Ra}$ to $15 \%$ for ${ }^{223} \mathrm{Ra}$ and ${ }^{222} \mathrm{Rn}$ estimates. 


\section{DISCUSSION}

\subsection{Efficiency of burrow flushing}

The best estimate of the water flux through burrows is based on the assumption that flushing of the macro burrows typical of those shown in Fig. 2 dominates the radionuclide flux from forest sediment. Aller (1980) showed that enhanced diffusion of solutes from muddy marine sediment can also be caused by bioirrigation of micro burrows (diameter $\sim 0.1 \mathrm{~cm}$ ) potentially present within the surface $15 \mathrm{~cm}$ of sediment. We have no data to quantify the extent of this effect but we saw no visual evidence for the presence of small burrows. High densities of these burrows would likely be reflected by high sediment porosity but our value of 0.73 is not high for wetted fine-grained sediment. In addition, the sediment inundation period $(i)$ of 0.3 day would restrict bioirrigation to just $30 \%$ of values observed in permanently inundated coastal sediment. Finally, enhanced diffusion via irrigation of small burrows would enhance the sediment flux of short-lived $\mathrm{Ra}$ isotopes, ${ }^{224} \mathrm{Ra}$ and ${ }^{223} \mathrm{Ra}$, relative to ${ }^{228} \mathrm{Ra}$. Yet we find that flux enhancement from the Coral Creek forest is greatest for ${ }^{228} \mathrm{Ra}$ (Section 3.2.5). We therefore conclude that flushing of macro burrows rather than micro burrows dominates radionuclide fluxes.

At a representative burrow volume of $70 \mathrm{~L}$ and a burrow density of 1.8 burrows $\mathrm{m}^{-2}$ (Stieglitz et al., 2000b), and the best estimates of the water flux of $30.4 \pm 4.7 \mathrm{~L} \mathrm{~m}^{-2}$ day $^{-1}$, $12 \pm 2 \%$ of the total burrow volume is flushed each tidal cycle (at 2 tidal cycles per day). This is lower than previous estimates of $100 \%,<30 \%$ and $25-30 \%$ by Stieglitz et al. (2000b), Hollins and Ridd (unpubl.) and Heron and Ridd (2003) respectively. In these previous works, the flushing rate of individual burrows was estimated using electrical conductivity, oxygen, and a combination of dye tracing and modelling. Individual burrow estimates may not be representative for all burrows in a forest, and indeed, the results of this study indicate that the average flushing efficiency in a forest is lower. Burrow flushing is driven by the water level difference across multiple openings (Ridd, 1996), and this water level difference is not necessarily constant with distance from the creek given the topographic variations of the forest and friction effects on the sub-aerial mangrove roots (Mazda et al., 1997). Thus it is likely that burrows located further away from the creek are flushed less efficiently. The apparent discrepancies between upscaling and downscaling approaches could be resolved in the future by recording creek-normal transects of burrow flushing rate. In contrast to previously published single-burrow calculations, the radiochemical methods employed herein provide a forest-scale estimate of the extent animal burrows can influence the flux of solutes from intertidal sediment into seawater. Such creek/forest-scale estimates provide a more reliable estimate of large-scale mangrove forest solute export, where estimates over 10 's to 100 's of $\mathrm{km}$ of coastline are required.

\subsection{Regional impacts - the 'mangrove pump'}

The regional importance of the tidally-driven circulation of seawater through burrows in a mangrove forest relative to riverine freshwater fluxes along a coastline can be assessed by upscaling the results of this study from a representative mangrove forest-creek system. Mangrove forests in the Hinchinbrook Island region cover a total area of $210 \mathrm{~km}^{2}$ (www.ozcoast.org.au). This area is completely inundated only at the highest annual tides of approximately $1.7 \mathrm{~m}$ AHD. The yearly average tidal height is approximately $1.1 \mathrm{~m}$ (cf. tide tables by Australian Hydrographic Office), and thus the annually averaged area of inundated mangrove forest in the Hinchinbrook region is estimated at $136 \mathrm{~km}^{2}$. At a daily flux of $30.4 \pm 4.7 \mathrm{~L} \mathrm{~m}^{-2}$ of forest floor, a total water volume of $1.5 \pm 0.2 \mathrm{~km}^{3}$ year $^{-1}$ is exchanged between burrows and creeks, and subsequently exported into the coastal zone (with a typical residence time of 4 days in the creek, as calculated from radium isotope ratios). In comparison, the major river in the Hinchinbrook region, the Herbert River (Fig. 1), is the second largest river in the central Great Barrier Reef catchment, with an annual average freshwater river discharge of $4.0 \mathrm{~km}^{3}$ year ${ }^{-1}$ (Furnas and Mitchell, 2000). Thus, the volume of seawater circulation through mangrove forest sediments in the Hinchinbrook region is equivalent to between $31 \%$ and $43 \%$ of the annual average river flow of one of the largest rivers in the region.

Dittmar and Lara (2001) showed that the nutrient export from mangroves in the Brazilian Caete estuary exceeded that of the hinterland, despite mangroves only occupying $6 \%$ of the catchment $(1-3 \%$ of the Amazon river's discharge). In addition, previous detailed evaluation of the carbon flux into the Hinchinbrook Channel showed that mangrove forests contributed nearly twice the flux as the river (Alongi et al., 1998). In analogy to the vertically operating 'biological pump' of carbon in the ocean (e.g. De La Rocha, 2007), the results of the study presented here illustrate well the hydrological mechanism of the tidal 'mangrove pump', pumping water through animal burrows, which is suggested here to play a key role in this carbon release. Aside from the significant comparative magnitude of this water flux, its biogeochemical implications must be considered significant also from a temporal aspect: the tidally-driven seawater recirculation occurs all-year round, whereas river discharge is highly seasonal.

Finally, it is instructive to upscale further to the mangrove forests of the entire Wet Tropics region, which covers the central Great Barrier Reef between $15.5^{\circ} \mathrm{S}$ and $18.8^{\circ} \mathrm{S}$ and is the region of the continent with the highest rainfall (and thus greatest river discharge). Whilst there are differences in factors such as forest structure, sediment characteristics or burrow density, it is likely that the flushing of the forest floor via burrows remains the dominant sediment-water interaction in the mangrove forests throughout the region. Assuming the daily water flux value of $30.4 \pm 4.7 \mathrm{~L} \mathrm{~m}^{-2}$ is representative for the mangrove forests of the Australian Wet Tropics (central Great Barrier Reef) region, with a total forest area of $390 \mathrm{~km}^{2}$ and an inundation-effective area of $252 \mathrm{~km}^{2}$, the total annual water exchange through animal burrows in mangroves is estimated to be between 2.3 and $3.3 \mathrm{~km}^{3}$ year $^{-1}\left(2.8 \pm 0.5 \mathrm{~km}^{3}\right.$ year $\left.^{-1}\right)$. Compared with an annual average freshwater influx from the region's rivers 
of $14.5 \mathrm{~km}^{3}$ year $^{-1}$ (Furnas and Mitchell, 2000), the mangrove pump thus may constitute between $16 \%$ and $22 \%$ of the river discharge on a coastal scale of many hundreds of kilometres. In summary, the mangrove pump should be considered a significant hydrological process supporting water fluxes - and associated solute fluxes - across the entire Wet Tropics coastline, especially when the enhanced solute (e.g. carbon) concentration of burrow water is considered. Finally, in other regions along the tropical coastline of Australia (e.g. the Gulf of Carpentaria) or elsewhere, where annual average river flows are significantly smaller than in the Wet Tropics, and mangrove forests significantly larger, this study indicates that the annual water circulation through mangrove forest floors could exceed annual river flows.

\section{CONCLUSIONS}

Significant export of radionuclides from the forest to Coral Creek demonstrates tidally-driven water circulation through burrows. The flushing of animal burrows by this tidal 'mangrove pump' is an important and efficient hydrological pathway for the export of solutes from the productive subsurface on mangrove forest floors to the creek, and subsequently to the near-shore ocean. A residence time of $4.2 \pm 0.2$ days for water in Coral Creek indicates efficient tidal flushing of creek water to the coastal ocean. In conclusion, it is suggested that seawater recirculation through mangrove burrows is an important route for land-ocean solute exchange in the tropics, with tidal flushing of burrows being the 'motor' of water and solute exchange in and from mangrove forests, supporting continuous exports of soluble organic and inorganic matter from mangrove forests to the coastal ocean. Importantly, on regional scale of the central Great Barrier Reef, the annual water flux circulated by this tidally-driven 'mangrove pump' through animal burrows is on the order of $20 \%$ of total annual river discharge in the region.

\section{ACKNOWLEDGMENTS}

Peter V. Ridd (James Cook University) advised on mixing loss calculations. Peter G. Cook (CSIRO Land and Water Adelaide) provided liquid scintillation measurements of radon burrow samples, and Gregg Brunskill and John Pfitzner (Australian Institute of Marine Science) helped with the collection of radium data in 1997. Clwedd Burns and Peter Arthofer (JCU) provided field support, and Clive Grant, Jeff Cavanagh and Paul Givney (JCU) provided logistical and technical support. Eric Wolanski (Australian Institute of Marine Science) is thanked for making original Coral Creek forest topography data available, which Sarah Searson (JCU) converted to digital format. We thank Sebastien Hervé for artwork support. The constructive comments of two anonymous reviewers greatly improved the manuscript. The study was partially funded by an Academic Senate Grant to JFC from the University of California Santa Barbara. Development of the continuous radon technique was funded by the Australian Research Council (Discovery Grant DP0209526) and James Cook University (Merit Research Grant 13827). This is a contribution from the Nereis Park - The Bioturbation World (www.nereispark.org).

\section{REFERENCES}

Aller R. C. (1980) Quantifying solute distributions in the bioturbated zone of marine sediments by defining an average microenvironment. Geochim. Cosmochim. Acta 44, 1955-1965.

Alongi D. M. (1994) The role of bacteria in nutrient recycling in tropical mangrove and other coastal benthic ecosystems. Hydrobiologia 285, 19-32.

Alongi D. M. T., Ayukai T., Brunskill G. J., Clough B. F. and Wolanski E. (1998) Sources, sinks, and export of organic carbon through a tropical, semi-enclosed delta (Hinchinbrook Channel, Australia). Mangroves Salt Marshes 2, 237-242.

Ayukai T., Miller D., Wolanski E. and Spagnol S. (1998) Fluxes of nutrients and dissolved and particulate organic carbon in two mangrove creeks in northeastern Australia. Mangroves Salt Marshes 2, 223-230.

Berelson W. M., Buchholtz M. R., Hammond D. E. and Santschi P. H. (1987) Radon fluxes measured with the MANOP Bottom Lander. Deep Sea Res. 34, 1209-1228.

Boto K. and Bunt J. S. (1981) Tidal export of particulate organic matter from a northern Australian mangrove system. Estuarine Coastal Shelf Sci. 13, 247-255.

Boto K. G., Alongi D. M. and Nott A. L. J. (1989) Dissolved organic carbon-bacteria interactions at sediment-water interface in a tropical mangrove system. Mar. Ecol. Prog. Ser. 51, 243-251.

Boudreau B. P. (1996) The diffusive tortuosity of fine-grained unlithified sediments. Geochim. Cosmochim. Acta 60, 31393142.

Bouillon S., Middelburg J. J., Dehairs F., Borges A. V., Abril G., Flindt M. R., Ulomi S. and Kristensen E. (2007) Importance of intertidal sediment processes and porewater exchange on the water column biogeochemistry in a pristine mangrove creek (Ras Dege, Tanzania). Biogeosciences 4(1), 317-348.

Bouillon S., Borges A. V., Catañeda-Moya E., Diele K., Dittmar T., Duke N. C., Kristensen E., Lee S. Y., Marchand C., Middelburg J. J., Rivera-Monroy V. H., Smith, III, T. J. and Twilley R. R. (2008) Mangrove production and carbon sinks: a version of global budget estimate. Global Biogeochem. Cycles 22, GB2013. http://dx.doi.org/10.1029/2007GB003052.

Bunt J. S. and Bunt E. D. (1999) Complexity and variety of zonal pattern in the mangroves of the Hinchinbrook area, Northeastern Australia. Mangroves Salt Marshes 3, 165-176.

Burnett W. C., Aggarwal P. K., Bokuniewicz H., Cable J. E., Charette M. A., Kontar E., Krupa S., Kulkarni K. M., Loveless A., Moore W. S., Oberdorfer J. A., Oliveira J., Ozyurt N., Povinec P., Privitera A. M. G., Rajar R., Ramessur R. T., Scholten J., Stieglitz T., Taniguchi M. and Turner J. V. (2006) Quantifying submarine groundwater discharge in the coastal zone via multiple methods. Sci. Total Environ. 367, 498-543.

Clark J. F., Schlosser P., Simpson H. J., Stute M., Wanninkhof R. and Ho D. T. (1995) Relationship between gas transfer velocities and wind speeds in the tidal Hudson River determined by the dual tracer technique. In Air-Water Gas Transfer (eds. B. Jähne and E. Monahan). Aeon Verlag, Hanau, Germany, pp. 785-800.

Cook P. G., Favreau G., Dighton J. C. and Tickell S. (2003) Determining natural groundwater influx to a tropical river using radon, chlorofluorocarbons and ionic environmental tracers. J. Hydrol. 277, 74-88.

Crusius J., Koopmans D., Bratton J. F., Charette M. A., Kroeger K., Henderson P., Ryckman L., Halloran K. and Colman J. A. (2005) Submarine groundwater discharge to a small estuary estimated from radon and salinity measurements and a box mode. Biogeosciences 2, 141-157. 
De La Rocha C. L. (2007) The biological pump. Treat. Geochem. 6, 1-29. http://dx.doi.org/10.1016/B0-08-043751-6/06107-7.

Dittmar T. and Lara R. J. (2001) Driving forces behind nutrient and organic matter dynamics in a mangrove tidal creek in north Brazil. Estuarine Coastal Shelf Sci. 52, 249-259.

Dittmar T., Hertkorn N., Kattner G. and Lara R. J. (2006) Mangroves, a major source of dissolved organic carbon to the oceans. Global Biogeochem. Cycles 20, GB1012. http:// dx.doi.org/10.1029/2005GB002570.

Dulaiova H. and Burnett W. C. (2006) Radon loss across the water-air interface (Gulf of Thailand) estimated experimentally from ${ }^{222} \mathrm{Rn}-{ }^{224} \mathrm{Ra}$. Geophys. Res. Lett. 33, L05606. http:// dx.doi.org/10.1029/2005GL025023.

Furnas M. and Mitchell A. (2000) Runoff of terrestrial sediment and nutrients into the Great Barrier Reef world heritage area. In Oceanographic Processes of Coral Reefs (ed. E. Wolanski). CRC Press, pp. 37-52.

Hancock G. J., Webster I. T., Ford P. F. and Moore W. S. (2000) Using $\mathrm{Ra}$ isotopes to examine transport processes controlling benthic fluxes into a shallow estuarine lagoon. Geochim. Cosmochim. Acta 64, 3685-3699.

Hancock G. J., Webster I. T. and Stieglitz T. C. (2006) Horizontal mixing of Great Barrier Reef waters: offshore diffusivity determined from radium isotope distribution. J. Geophys. Res. 111, C12019. http://dx.doi.org/10.1029/2006JC003608.

Heron S. F. and Ridd P. V. (2003) The effect of water density variations on the tidal flushing of animal burrow. Estuarine Coastal Shelf Sci. 52, 411-421. http://dx.doi.org/10.1006/ ecss.2000.0761.

Holguin G., Vazquez P. and Bashan Y. (2001) The role of sediment microorganisms in the productivity, conservation, and rehabilitation of mangrove ecosystems: an overview. Biol. Fertil. Soils 33, 265-278. http://dx.doi.org/10.1007/s003740000319.

Hollins S. E., Ridd P. V. and Read W. W. (2000) Measurement of the diffusion coefficient for salt in salt flat and mangrove soils. Wetl. Ecol. Manag. 8, 257-262.

Jähne B., Münnich K. O., Bösinger R., Dutzi A., Huber W. and Libner P. (1987) On parameters influencing air-water gas exchange. J. Geophys. Res. 92, 1937-1949.

Kristensen E., Bouillon S., Dittmar T. and Marchand C. (2008) Organic carbon dynamics in mangrove ecosystems: a review. Aquat. Bot. 89, 201-219.

Li Y.-H. and Gregory S. (1974) Diffusion of ions in sea water and in deep-sea sediments. Geochim. Cosmochim. Acta 38, 703-714.

Mazda Y., Wolanski E., King B., Sase A., Ohtsuka D. and Magi M. (1997) Drag force due to vegetation in mangrove swamps. Mangroves Salt Marshes 1, 193-199.

Moore W. S. (1976) Sampling radium-228 in the deep ocean. Deep Sea Res. 23, 647-651.

Moore W. S. (2007) Seasonal distribution and flux of radium isotopes on the Southeastern U.S. continental shelf. J. Geophys. Res. Oceans 112, C10013. http://dx.doi.org/10.1029/ 2007JC004199.

Moore W. S. (2010) The effect of submarine groundwater discharge on the ocean. Ann. Rev. Mar. Sci. 2, 59-88.

Moore W. S. and Arnold R. (1996) Measurement of ${ }^{223} \mathrm{Ra}$ and ${ }^{224} \mathrm{Ra}$ in coastal waters using a delayed coincidence counter. $J$. Geophys. Res. 101, 1321-1329.
Murray A. S., Marten R., Johnston A. and Martin P. (1987) Analysis for naturally occurring radionuclides at environmental levels by gamma spectrometry. J. Radioanal. Nucl. Chem. 115, 263-288.

Ridd P. V., Wolanski E. and Mazda Y. (1990) Longitudinal diffusion in mangrove-fringed tidal creeks. Estuarine Coast Shelf Sci. 31, 541-554.

Ridd P. V. (1996) Flow through animal burrows in mangrove creeks. Estuarine Coast Shelf Sci. 43, 617-625.

Ridd P. V. and Stieglitz T. (2002) Dry season salinity changes in tropical mangrove and saltflat fringed estuaries. Estuarine Coast Shelf Sci. 54, 1039-1049.

Robertson A. I. and Daniel P. A. (1989) The influence of crabs on litter processing in high intertidal mangrove forests in tropical Australia. Oecologia 78(2), 191-198. http://dx.doi.org/10.1007/ BF00377155.

Robertson A. I. and Alongi D. M. (1995) Role of riverine mangrove forests in organic carbon export to the tropical coastal ocean; a preliminary mass balance for the Fly Delta (Papua New Guinea). Geo-Mar. Lett. 15(3-4), 134-139.

Scully N. M., Maie N., Dailey S. K., Boyer J. N., Jones R. D. and Jaffé R. (2004) Early diagenesis of plant derived dissolved organic matter along a wetland, mangrove, estuaryecotone. Limnol. Oceanogr. 49, 1667-1678.

Smith, III, T. J., Boto K. G., Frusher S. D. and Giddins R. L. (1991) Keystone species and mangrove forest dynamics: the influence of burrowing by crabs on soil nutrient status and forest productivity. Estuarine Coastal Shelf Sci. 51, 419-432.

Smith N., Wilcox C. and Lessman J. L. (2009) Fiddler crab burrowing affects growth and production of white mangrove (Lagunculariaracemosa) in a restored Florida coastal marsh. Mar. Biol. 156, 2255-2266. http://dx.doi.org/10.1007/s00227009-1253-7.

Stieglitz T., Ridd P. V. and Hollins S. (2000a) A small sensor for detecting animal burrows and monitoring burrow water conductivity. Wetl. Ecol. Manag. 8, 1-7.

Stieglitz T., Ridd P. and Müller P. (2000b) Passive irrigation and functional morphology of crustacean burrows in a tropical mangrove swamp. Hydrobiologia 421, 69-76.

Stieglitz T. (2005) Submarine groundwater discharge into the nearshore zone of the Great Barrier Reef, Australia. Mar. Pollut. Bull. 51, 51-59.

Stieglitz T. C., Cook P. G. and Burnett W. C. (2010) Inferring coastal processes from regional-scale mapping of 222Radon and salinity: examples from the Great Barrier Reef, Australia. J. Environ. Radioact. 101, 544-552.

Wolanski E., Jones M. and Bunt J. S. (1980) Hydrodynamics of a tidal creek-mangrove swamp system. Aust. J. Mar. Freshwat. Res. 31, 431-450.

Xin P., Jina G., Li L. and Barry D. A. (2009) Effects of crab burrows on pore water flows in salt marshes. Adv. Water Resour. 32(3), 439-449.

Associate editor: Jerome Gaillardet 